\title{
The Impact of Factors on Reverse Technology Flow of Multinational R\&D Centers: A Review of Literatures
}

\author{
Dongming Zhang ${ }^{1, *}$
}

\author{
${ }^{1}$ Department of Science and Technology, Beijing Open University, Beijing, China \\ *Corresponding author. Email: jiahao0913@163.com
}

\begin{abstract}
With continuous emergence of multinational R\&D centers, the influencing factors on reverse technology flow performance are becoming research focus. This article redefines the concept of reverse technology flow, and then does a literature review on influencing factors on both initial and final phase of reverse technology flow. It finds out characteristics of multinational R\&D centers, relevant environment of home countries and host countries, which impact either the initial phase or the final phase, have been more studied, while lacking research on the whole process of reverse technology flow. Is there any factor impact both the initial phase and the final phase? The question would be necessarily discussed more in future research. On the other hand, with more and more multinational R\&D centres from developing countries being built, reverse technology flow of multinational R\&D centres of developing countries needs further studied.
\end{abstract}

Keywords: reverse technology flow, multinational $R \& D$ center, two-phase framework, influencing factors

\section{INTRODUCTION}

Different from traditional multinational investments based on business ownership advantage, nowadays more and more multinational R\&D investments aim for seek technology are becoming an important global strategy for multinational corporations (MNCs). Back to 1990s, Kogut \& Chang (1991) [1] thought the purposes of Japan and America respectively set up R\&D centers in America and European Union were to acquire technology spillovers from their host countries. Lots of literatures on international R\&D also gave their evidence that the motivation of technology sourcing facilitated outward foreign investments (OFDI) (Cantwell, 1995 [2]; Cantwell \& Janne, 1999 [3], Fosfuri \& Motta, 1999 [4]). Driffield \& Love (2003) [5] drew on former theory and firstly did empirical study based on UK industrial panel data, which examined the existence of reverse spillovers that spillovers from host countries to subsidiaries of foreign multinational companies. Håkanson \& Nobel (2000, 2001 [6]), who are the first to use the term "reverse technology transfer" in paper to refer to the transfer process of the technology from multinational R\&D centers to their headquarters, have done surveys to 110 managers of R\&D lab located in Europe and North America from 17 Sweden MNCs, they found more than half R\&D labs transferred the new sourced technology from the host countries to their headquarters, which suggested R\&D lab can acquire technology from the host environment.
Recently, multinational R\&D investment aiming for reverse technology flow has been also an ongoing trend among developing countries particularly emerging countries such as China, India, etc. Thus, it's necessary to understand this trend. Impact factors of reverse technology flow are critical to whether or not the multinational R\&D centers can be successful to acquire the new technology from host countries and transfer it to headquarters. This article reviews the relevant literatures to better understand the phenomenon.

\section{DEFINITION AND ANALYTIC FRAMEWORK}

During the process of reverse technology, the article attempts to divide the completed reverse technology flow into the initial phase and the final phase. The initial phase is that the multinational $R \& D$ center first acquires the technology from the host country, and the final phase namely the multinational R\&D center transfers the acquired technology to the parent company phase ("Fig. 1").

Thus, this article reviews the literatures respectively from the initial phase and final phase, so that clarify and sort out the factors impacts multinational R\&D center's acquirement and transformation. 


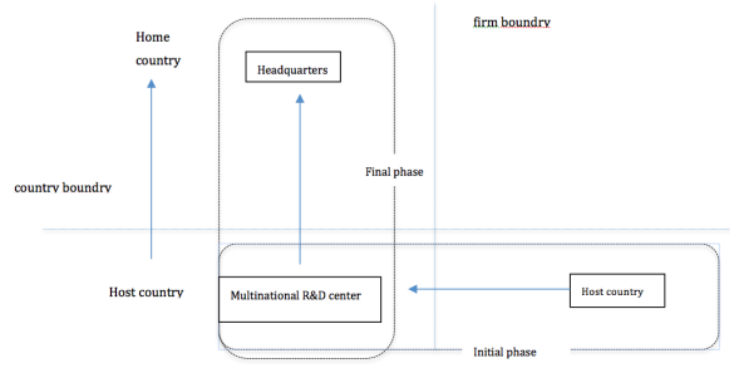

Fig. 1. The two phases of reverse technology flow.

\section{INFLUENCING FACTORS AT THE INITIAL PHASE OF REVERSE TECHNOLOGY FLOW}

Existing research on the initial phase of reverse technology flow mainly explores factors impact on the innovation performance of multinational R\&D centers from multinational $R \& D$ centers and the relationship between multinational $R \& D$ centers and parent companies.

In terms of multinational $\mathrm{R} \& \mathrm{D}$ centers, their degree of embedding in host countries and multinational companies, as well as the multinational R\&D centers' own technical capabilities, all affect the innovation performance of $\mathrm{R} \& \mathrm{D}$ centers in the host country environment. Embedding is divided into external embedding and internal embedding. The importance of external embedding stems from the theory of the disadvantage of outsiders. Due to the inability of foreigners (liability of foreignness), multinational R\&D centers often encounter obstacles in host country, making it difficult to integrate into local knowledge networks. However, in order to obtain knowledge, multinational R\&D centers must be embedded in local scientific and engineering organizations to obtain further communication with the local environment (Hymer, 1976). Singh (2008) pointed out that the disadvantage of outsiders may result from the inability of multinational companies to access tacit knowledge embedded in regional social networks. The two-way communication between the multinational $\mathrm{R} \& \mathrm{D}$ center and the social organization of the community is very important for the $\mathrm{R} \& \mathrm{D}$ center to acquire and digest tacit knowledge. Some knowledge recipients usually have difficulty in fully absorbing the received knowledge when they communicate for the first time. Opportunity can achieve digestion and transformation (Hansen, 1999 [7]). Cohen \& Levinthal (1990) [8] and Lane \& Lubatkin (1998) [9] also believe that the more multinational R\&D institutions can be embedded in the local environment, the more they can develop a knowledge processing system similar to local research partners, which shows that simply establishing a R\&D center in the host country is insufficient. In order to access and absorb knowledge, it is necessary to establish social relations in the local area to benefit from the flow of knowledge. External embedding is essential for generating social capital and establishing social relationships of mutual trust to obtain core technical knowledge in local organizations including companies, universities, and public research institutions (Yoneyama, 2012 [10]).

Internal embedding refers to the multinational $R \& D$ center as a subsidiary of a multinational company, embedded in the global network of multinational companies, especially the relationship with its headquarters, which has an important impact on its innovation performance in the host country (Williams and Nones, 2009 [11]; Song et al., 2011 [12]). The parent company's involvement in the innovation activities of multinational $R \& D$ centers will have both positive and negative effects. Relatively more scholars in the existing research have paid attention to the negative effects, such as Asakawa (2001a) [13] pointed out that the strong linkage relationship between multinational $R \& D$ centers and the parent company is restricted. The autonomy of multinational $R \& D$ centers has been reduced, thus reducing their level of knowledge acquisition in the host country. Ambos \& Reitsperger (2004) [14] also insist that a higher degree of social relationship between the multinational $R \& D$ center and the parent company will reduce its opportunities to develop technology in the host country. Based on these points of view, Song et al. (2011) [15] also assumed that when multinational $R \& D$ centers have strong internal embedding, the probability of acquiring technology in the host country will be lower.

The multinational R\&D center's own technical capabilities and absorption capabilities also affect its technical knowledge acquisition in host country. In order to identify, acquire and digest valuable external knowledge, especially tacit knowledge, an enterprise must possess a certain level of relevant technical absorptive capacity (Cohen \& Levinthal, 1990) [8]. Absorptive capacity point of view shows that when multinational companies and their multinational R\&D centers have strong technical capabilities, it is easier to absorb and expand technology in the host country. When multinational R\&D centers improve their technological capabilities and absorptive capacity, they will also help them upgrade from host country innovators to global innovators to a certain extent. (Medcof, 1997 [16]; Nobel \& Birkinshaw, 1998 [17]; Singh, 2005 [18]). The strong technical capabilities of multinational $R \& D$ centers will help them to perceive and acquire knowledge in the unfamiliar host country environment. When the acquired host country knowledge reaches a certain level, the value of the multinational R\&D center's technical capabilities will gradually decline. According to this, Song (2011) assumes an inverted "u" relationship between technological capabilities and multinational R\&D centers. 
The relationship between multinational R\&D centers and parent companies is mainly distinguished by "centralization and decentralization" or "centralization and autonomy" (Behrman \& Fischer, 1980 [19]; Hakanson \& Zander, 1986 [20]). Behrman \& Fischer (1980) draws on four forms of parentsubsidiary relationship, namely: (1) absolute centralization; (2) partial centralization; (3) regulatory freedom; (4) complete freedom. Nohria \& Ghoshal (1994) [21] believe that when subsidiaries have a relatively high degree of autonomy, it would be more conducive to create and develop technical knowledge. Similar conclusions have been drawn by Foss and Pedersen (2002) [22] and Cantwell and Mudambi (2005) [23]. Subsidiaries more independent are more responsive to local strategic proposals (Bartlett \& Ghoshal, 1989) [24] and can penetrate the local environment to form a strategic knowledge system (Andersson et al., 2002 [25]; Zanfei, 2000 [26]). However, a few scholars have drawn a negative results (Brockhoff \& Schmaul, 1996 [27]; Frost et al., 2002 [28]). In addition, some scholars such as Ghoshal \& Bartlett (1988) found that the degree of autonomy of multinational R\&D centers in the host country is related to the form of technological innovation tasks (creative, adaptive or diffuse) undertaken. Therefore, it is believed that the relationship between the parent company and the multinational R\&D center cannot be simply divided by centralization and autonomy. Generally, R\&D centers that undertake creative tasks usually have higher autonomy.

Above theoretical basis originated from exploration and summarization of technology-seeking multinational investment in developed countries. Obviously, relevant empirical research more takes developed countries such as Japan as research samples (such as Song et al., 2011).

\section{INFLUENCING FACTORS OF THE FINAL PHASE OF REVERSE TECHNOLOGY FLOW}

The research on the influencing factors on the final phase can be summarized as external factors and internal factors. External factors such as technology characteristics and reverse technology transfer mechanism, etc. Internal factors are mainly explored from multinational R\&D centers, parent companies and the relationship between the two.

The impact of technology characteristics on reverse technology transfer was explained for the first time in research by Håkanson \& Nobel (2000). The authors believe that reverse technology transfer will only occur when the technology transferred allows the parent company to obtain exclusiveness in the market, which means that the technology transferred to the parent company is usually difficult to be imitated by other companies. Tacit knowledge conforms to the above characteristic. Based on the resource-based view, the author proposes that technical characteristics including the articulability, observability, and team dependence of technology knowledge negatively affect the reverse technology transfer behavior of multinational R\&D centers to the parent company.

The technical capabilities of multinational R\&D centers also play an important role in the final phase, but their contributions to the knowledge stock of multinational companies vary (Gupta \& Govindarajan, 1991), which is related to the role of subsidiaries played in multinational companies. Generally, the technical capabilities of R\&D centers dedicated to the flow of knowledge are highly rated (Monteiro et al., 2008). It can be presumed that the higher the technological capabilities of the multinational R\&D center, the more favorable the reverse technology transfer is when the multinational subsidiary transfers technology to their parent company. Nair. et al (2016) [29] also proposed that the reverse knowledge transfer from the multinational $R \& D$ center to the Indian parent company is positively related to the $R \& D$ center's technical capabilities.

The absorptive capacity of the parent company has a positive relationship with reverse technology transfer (Nair. et al, 2016), this view inherits the research by Gupta \& Govindarajan (2000). Gupta \& Govindarajan (2000) concludes that when there is a gap in the knowledge ability of a certain aspect, the higher the absorptive ability of knowledge receiver is, the easier it obtain benefit from the knowledge flow. The multinational $R \& D$ centers of multinational companies in emerging economies aim to find advanced technologies that are not available in the home country to enhance the competitiveness of the parent company. Based on this, the author proposes that the reverse technology transfer from Indian multinational subsidiaries to the parent company is positively related to the absorption capacity of the parent company.

The impact of the relationship between the multinational $R \& D$ center and the parent company is mainly due to the effect of the coordination mechanism between the two on reverse technology transfer. Ambos \& Ambos (2009) [30] divided the coordination mechanism into technical coordination mechanisms (TCM) and personal coordination mechanisms (PCM). Among them, technical facilities, which include business intelligence, collaboration software, etc., play an important role in reverse technology transfer, and can support employees to encode, store and obtain timely knowledge. At the same time, the author also puts forward the moderating effect of distance on the above-mentioned influence relationship. Distance includes four latitudes of culture, management, geography and economy (Ghemawat, 2001) [31].

Some research took developing countries as research samples, empirically analyzing the impact of 
factors on reverse technology transfer such as knowledge characteristics, multinational R\&D centers, parent companies, and the relationship between them. For example, Nair.et al (2016) took 329 multinational companies (multinational M\&As) in Indian as research samples, and verified the positive impact of knowledge relevance, multinational $R \& D$ center technical capabilities and parent company's absorptive capacity on reverse technology transfer. Among them, the parent company's absorptive capacity is an intermediary variable, and knowledge correlation is a moderating variable. Borini (2012) [32] conducted a questionnaire survey on 66 multinational subsidiaries of 30 multinational companies in Brazil. It was also concluded that the earlier the multinational R\&D center was established, the stronger the adaptability of the multinational R\&D center was in host country, thereby making it easier to obtain technology spillovers from the host country. Athreyeet al. (2013) [33] obtained first-hand data from 2009 to 2011 through high-level interviews with Fiat Group and its R\&D subsidiaries established in Turkey, Brazil and India, and obtained second-hand patents from the US Patent Office for the group. With qualitatively analyzing, the difference in management philosophy between the parent company and the subsidiary is one of the factors that affect the effect of multinational R\&D reverse technology spillovers.

\section{INFLUENCING FACTORS OF THE WHOLE PROCESS OF REVERSE TECHNOLOGY FLOW}

Research on reverse technology flow used to follow traditional perspectives of technology itself, sender and receiver. Among them, the impact of technology characteristics on reverse technology flow cannot be ignored. Gupta \& Govindarajan (2000) believes that the relevance of target technology knowledge plays an important role in technology flow, especially the attractiveness of technology knowledge is an important factor for technology receivers to consider whether to accept. The relevance of technical knowledge is also a key condition for the flow of technology. Schulz (2001) [34] holds the same view.

In terms of empirical research, Chen et al. (2012) directly studied the impact of the host country's environment on reverse technology flow, which is a more general study of the reverse process of reverse technology flow. The authors are based on India, Turkey, Istanbul 2000-2008, 43 different The panel data of a total of 493 multinational companies in the industry shows that when multinational companies carry out R\&D activities in host countries with relatively high $R \& D$ capabilities, their technical capabilities will also be improved to a certain extent. Currently there is few studies' framework include both the initial phase and the final phase.

\section{CONCLUSION}

This article divides the reverse technology flow process into the initial phase and the final phase, and sorts out the influencing factors respectively from these two phases and the whole process. The study finds that the relationship between the multinational R\&D center and the parent company, knowledge characteristics, etc. have direct impact on both the initial and final phases. Other aspects such as characteristics of host country, multinational R\&D centers, and parent companies are important perspectives for the two-phase research.

Existing literature provides a rich theoretical basis and research perspectives for future research on reverse technology flow, but current two-phase research on reverse technology flow is not comprehensive, and the main research focuses on the only one phase of the process, either the initial phase or the final phase, lacking research on the whole process of reverse technology flow. The process of reverse technology flow especially factors occur and impact both two phases would be necessarily discussed more in future research. On the other hand, existing literatures do the research are more based on developed countries, with more and more multinational R\&D centres from developing countries being built, reverse technology flow of multinational $R \& D$ centres of developing countries needs further studied.

\section{References}

[1] Kogut B, Chang S J. Technological capabilities and Japanese foreign direct investment in the United States[J]. The Review of Economics and Statistics, 1991: 401-413.

[2] Cantwell J. The globalisation of technology: what remains of the product cycle model?Cambridge journal of economics, 1995, 19: $155-155$.

[3] Cantwell J, Janne O. Technological globalisation and innovative centres: the role of corporate technological leadership and locational hierarchy. Research policy, 1999, 28(2): 119-144.

[4] Fosfuri A, Motta M. Multinationals without advantages.The Scandinavian Journal of Economics, 1999, 101(4): 617-630.

[5] Driffield N, Love J H. Foreign direct investment, technology sourcing and reverse spillovers. The Manchester School, 2003 , 71(6): 659-672

[6] Håkanson L, Nobel R. Organizational characteristics and reverse technology transfer. MIR: Management International Review, 2001: 395-420.

[7] Hansen M T. The search-transfer problem: The role of weak ties in sharing knowledge across organization subunits. Administrative science quarterly, 1999, 44(1): 82-111.

[8] Cohen, WM and DA Levinthal. Absorptive capacity: A new perspective on learning and innovation. Administrative Science Quarterly ,1990, 35(1): 128- 152.

[9] Lane, PJ and M Lubatkin. Relative absorptive capacity and interorganizational learning. Strategic Management Journal , 1998, 19(5), 461- 477 .

[10] Yoneyama, S. Building external networks and its effect on the performance of overseas R\&D base. International Journal of Innovation Management , 2012, 16(3), 1- 18. 
[11] Williams, $\mathrm{C}$ and $\mathrm{B}$ Nones. $\mathrm{R} \& \mathrm{D}$ subsidiary isolation in knowledge-intensive industries: Evidence from Austria. R\&D Management , 2009, 39(2), 111- 123.

[12] Song, J, K Asakawa and Y Chu. What determines knowledge sourcing from hostlocations of overseas R\&D operations? A study of global R\&D activities of Japanese multinationals. Research Policy,2011,40(3):380-390

[13] Asakawa, K. Organizational tension in international R\&D management: The case of Japanese fi rms. Research Policy, 2001, 30(5): 735- 757.

[14] Ambos, B and WD Reitsperger. Offshore centers of excellence: Social control and success. Management International Review,2004, 44:51- 65 .

[15] Song J, Asakawa K, Chu Y. What determines knowledge sourcing from host locations of overseas R\&D operations?: A study of global R\&D activities of Japanese multinationals. Research Policy, 2011, 40(3): 380-390.

[16] Medcof, J.W. A taxonomy of internationally dispersed technology units and its application to management issues. R\&D Management,1997, 27 (4):301-318.

[17] Nobel, R., Birkinshaw, J. Innovation in multinational corporations: control and communication patterns in international R\&D operations. Strategic Management Journal,1998, 19 (5):479-496.

[18] Singh, J. Collaborative networks as determinants of knowledge diffusion patterns. Management Science 51,2005, (5):756-770.

[19] Behrman, JN and WA Fischer. Overseas R\&D Activities of Transnational Companies. Cambridge, MA: Oelgeschlager, Gunn and Hain,1980.

[20] Hakanson, L and U Zander. Managing International Research and Development .Stockholm, Sweden, SE: En Mekanpubliklikation, 1986.

[21] Nohria, N., Ghoshal, S. Differentiated fit and shared values: alternatives for managing headquarters-subsidiary relations. Strategic Management Journal,1994,15:491-502.

[22] Foss, N.J., Pedersen, T. Transferring knowledge in MNCs: the role of sources of subsidiary knowledge and organization context. Journal of International Management ,2002,8:49-67.

[23] Cantwell, J.A., Mudambi, R. MNE competence-creating subsidiary mandates. Strategic Management Journal,2005, 26:1109-1128

[24] Bartlett, C A, Ghoshal, S. Managing Across Borders: The Transnational Solution. Harvard Business School Press, Boston, 1989.

[25] Andersson, U., Forsgren, M., Holm, U. The strategic impact of external networks: subsidiary performance and competence development in the multinational corporation. Strategic Management Journal,2002, 23:979-996.

[26] Zanfei, A. Transnational firms and changing organisation of innovative activities. Cambridge Journal of Economics,2000, 24: 515-554.

[27] Brockhoff, K. K, Schmaul, B. Organization, autonomy, and success of internationally dispersed R\&D facilities. IEEE Transactions on Engineering Management,1996,43:33-40.

[28] Frost, T S, Birkinshaw, J. M., Ensign, P.C. Centers of excellence in multinational corporations. Strategic Management Journal,2002,23: 997-1018.

[29] Nair et al. Reverse knowledge transfer in emerging market multinationals: The Indian context . International Business Review,2016, 25:152-164.

[30] Ambos T C, Ambos B. The impact of distance on knowledge transfer effectiveness in multinational corporations. Journal of International Management, 2009, 15(1): 1-14

[31] Ghemawat P. Distance still matters. Harvard business review, 2001, 79(8): 137-147.
[32] Borini F M, de Miranda Oliveira M, Silveira F F, et al. The reverse transfer of innovation of foreign subsidiaries of Brazilian multinationals. European Management Journal, 2012, 30(3): 219-231

[33] Athreye, S G. Batsakis and S. Singh, 2013. Subsidiary embeddedness is a strategic choice: Complementarity and the factors associated with different types of embeddedness. DRUID Working Paper No. 13-05.

[34] Schulz. M. The Uncertain Relevance of Newness: Organizational Learning and Knowledge Flows. The Academy of Management Journal, 2004,4:661-681 